\title{
THREE NEW SPECIES AND A NEW GENUS OF HYPSELOSTOMATIDAE (GASTROPODA: PULMONATA) FROM CONG TROI CAVE, NORTHERN VIETNAM
}

\author{
Barna PÁll-Gergely ${ }^{1}$, Adrienne Jochum ${ }^{3,4}$ and Takahiro Asami ${ }^{2}$ \\ ${ }^{1}$ Department of Biology, Shinshu University, Matsumoto 390-8621, Japan \\ E-mail: pallgergely2@gmail.com \\ ${ }^{2}$ Department of Biology, Shinshu University, Matsumoto 390-8621, Japan \\ E-mail:asami99@shinshu-u.ac.jp \\ ${ }^{3}$ Naturhistorisches Museum der Burgergemeinde Bern, CH-3005 Bern, Switzerland \\ E-mail: adrienne.jochum@gmail.com \\ ${ }^{4}$ Institute of Ecology and Evolution, University of Bern, CH-3012 Bern, Switzerland
}

The Hypselostomatidae Zilch, 1959 comprise a family of minute pupilloid snails usually endemic to limestone habitats in single hills, adjacent hill ranges, and in caves of Southeast Asia. Except for one molecular study, their taxonomy is largely conchologically driven. In this work, shell material derived from sediment samples from the Cong Troi Cave in Northern Vietnam is examined and taxonomically assessed. Altogether, five species are recognized. Three new species are described: Angustopila stochi Páll-Gergely et Jochum, sp. n., Tonkinospira tomasini Páll-Gergely et Jochum sp. n. and Dentisphaera maxema PállGergely et Jochum, sp. n. For the latter species, Dentisphaera Páll-Gergely et Jochum a new genus is erected. Another hypselostomatid species is found to be identical with the original sample of Angustopila subelevata Páll-Gergely et Hunyadi, 2015 from Guangxi, China. This is the first record of $A$. subelevata from Vietnam. The fifth species closely resembles Pupisoma sp. from Thailand. Though figured here, it is not assessed taxonomically in this work.

Key words: cave snails, limestone habitats, Vietnam, micro snails.

\section{INTRODUCTION}

The family Hypselostomatidae Zilch, 1959 comprises a group of terrestrial snails characterized by shells smaller than $5 \mathrm{~mm}$. Most of these possess several teeth in their aperture. Although nearly all species and genera are known from shells, anatomical and molecular data have been reported in a few cases (TongKerd et al. 2004). According to Schileyko (1998), this family inhabits Indochina, Indonesia, Australia and the Philippines, and contains the following genera: Boysidia Ancey, 1881 (with the subgenera Paraboysidia Pilsbry, 1917 and Dasypupa Thompson et Dance, 1983), Anauchen Pilsbry, 1917, Bensonella Pilsbry et Vanatta, 1900, Aulacospira Möllendorff, 1890, Pseudostreptaxis Möllendorff, 1890, Gyliotrachela Tomlin, 1930, Hypselostoma Benson, 1856, Campolaemus Pilsbry, 1892, Boysia L. Pfeiffer, 1849 and Acinolaemus 
Thompson et Upatham, 1997. SсніLеуко (1998) concluded that Systenostoma Bavay et Dautzenberg, 1909 (currently Tonkinospira Jochum, Slapnik et PállGergely, 2014; not Systenostoma Marsson, 1887 [Bryozoa]) probably does not belong to Hypselostomatidae, but rather, to the Helicodiscidae due to the characteristic spiral sculpture. Later, he postulated that the genus is possibly related to Aulacospira as considered by Pilsbry (1917) or to Pupisoma Stoliczka, 1873 (Valloniidae) (SсніLеуко 2011). The hypselostomatid genus Angustopila Jochum, Slapnik et Páll-Gergely, 2014 was erected for some Thai and a Chinese species. Additional species were recently added to that genus from southern China (PÁlL-Gergely et al. 2015).

In the present paper, we examined microsnails from the Cong Troi Cave, Ha Giang Province, Northern Vietnam. We examined material collected at three different sites of the cave. We recognize five species, four of which are members of the Hypselostomatidae (Fig. 1). New species of Tonkinospira and Angustopila are described. A third new species is classified into its own genus (Dentisphaera gen. n.). The fourth hypselostomatid species is identical with the original sample of Angustopila subelevata Páll-Gergely et Hunyadi, 2015 from Guangxi, China. The fifth species shows affinity with Pupisoma sp. from Thailand (Panha \& Burch 2005), which belongs to the family Pupillidae, and though figured here, is not assessed taxonomically. Although all specimens

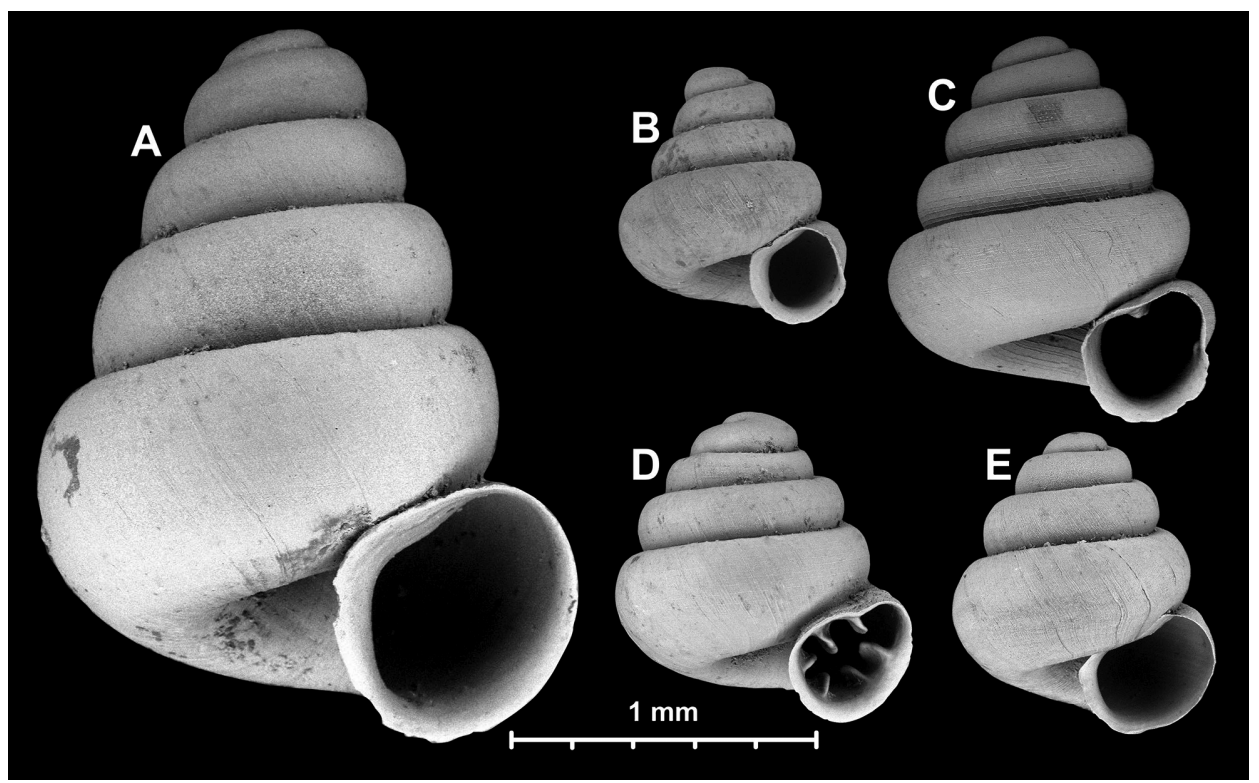

Fig. 1. Synoptic view of microsnails found in the Cong Troi Cave, Ha Giang Province, Northern Vietnam. $\mathrm{A}=$ Tonkinospira tomasini sp. n., $\mathrm{B}=$ Angustopila subelevata, $\mathrm{C}=$ Angustopila stochi sp. n., $\mathrm{D}=$ Dentisphaera maxema sp. $\mathrm{n} ., \mathrm{E}=$ Pupisoma (?) $\mathrm{sp}$. 
are known only from empty shells, we have no reason to believe that the species described here are extinct.

\section{MATERIALS AND METHODS}

The specimens were scooped by a plankton net (100 micrometers mesh size) from pools of drip water in Cong Troi Cave. Shells were cleaned with moistened, fine cosmetic brushes. After cleaning, the shells were viewed without coating under a low vacuum SEM (Miniscope TM-1000, Hitachi High-Technologies, Tokyo). Shell whorl number was counted to the nearest quarter whorl according to KERNEY and CAMERON (1979).

Measurements of the holotype of Angustopila stochi sp. n., were taken using SEM images. Measurements of all other shells were taken from images obtained by a Nikon Digital Sight DS-FI1 microscope camera attached to a Nikon SMZ 800 Zoom Stereomicroscope. For the species descriptions, shell measurements are expressed as ratios such as SW/SH and AW/AH.

Abbreviations: AH: aperture height, AW: aperture width, HNHM: Hungarian Natural History Museum (Budapest, Hungary), MZUF Natural History Museum University of Florence, Zoological Section "La Specola" Firenze (Florence, Italy), PGB: Collection Barna Páll-Gergely (Mosonmagyaróvár, Hungary), SD: standard deviation, SH: shell height, SW: shell width.

\section{TAXONOMIC DESCRIPTIONS}

Genus Angustopila Jochum, Slapnik et Páll-Gergely, 2014

Angustopila Jochum, Slapnik et Páll-Gergely, In: Jocнuм et al., ZooKeys 410: 26.

Type species: Systenostoma tamlod Panha et Burch 1999, by original designation.

Content: concava (Thompson et Upatham, 1997), dominikae Páll-Gergely et Hunyadi, 2015, elevata (Thompson et Upatham, 1997), huoyani Jochum, Slapnik et Páll-Gergely, 2014, fabella Páll-Gergely et Hunyadi, 2015, singuladentis Inkhavilay et Panha, 2016, subelevata Páll-Gergely et Hunyadi, 2015, stochi Páll-Gergely et Jochum, sp. n., szekeresi Páll-Gergely et Hunyadi, 2015, tamlod (Panha et Burch, 1999).

Distribution: This genus is distributed in northern Thailand, southern China and northern Vietnam (Fig. 7).

Angustopila stochi Páll-Gergely et Jochum sp. n.

$$
\text { (Figs 1C, 3A-H) }
$$

Type material: C03-N39 (locality code), Northern Vietnam, Ha Giang Province, Quan

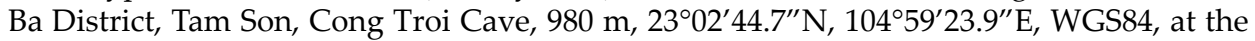


entrance, gours of dripping water, leg. G. TomAsIN, 28.01.2010., Holotype MZUF GC/49405; C04-N74 (locality code), Northern Vietnam, Ha Giang Province, Quan Ba District, Tam Son, Cong Troi Cave, $980 \mathrm{~m}, 2^{\circ} 02^{\prime} 44.7^{\prime \prime} \mathrm{N}, 104^{\circ} 59^{\prime} 23.9^{\prime \prime} \mathrm{E}$, WGS84, internal canyon, gours of dripping water, leg. G. Tomasin, 29.01.2010., MZUF GC/49412 (figured paratype, juvenile).

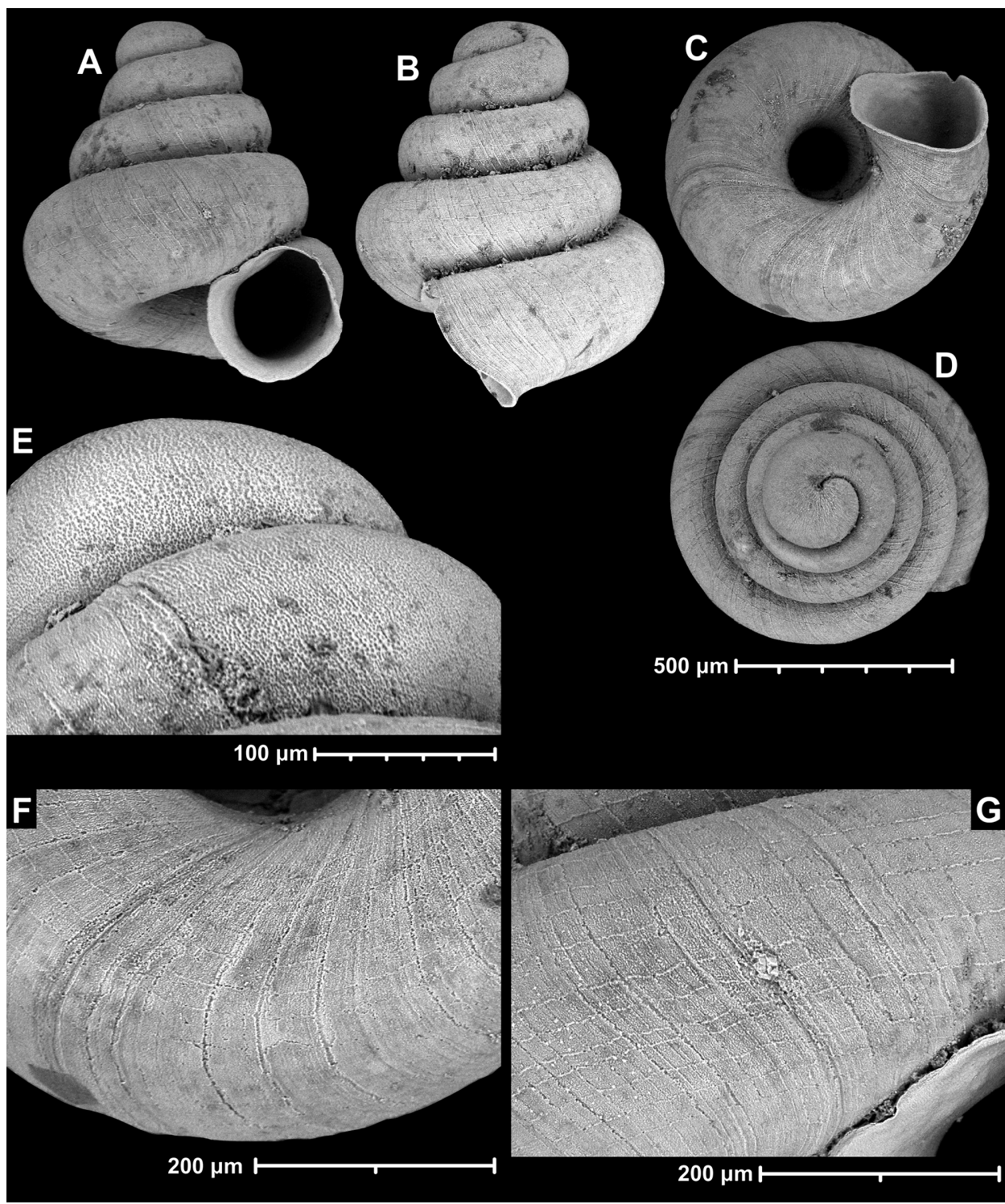

Fig. 2. Angustopila subelevata from Cong Troi Cave, Ha Giang Province, Northern Vietnam. $\mathrm{A}-\mathrm{D}=$ different views of the shell, $\mathrm{E}=$ protoconch, $\mathrm{F}=$ sculpture of the base of the shell (umbilical side), $\mathrm{G}=$ sculpture of the body whorl. 
Diagnosis: a tiny, convexly conic species with an ovate-subquadrate aperture, a tuberculated parietal and a low palatal denticle.

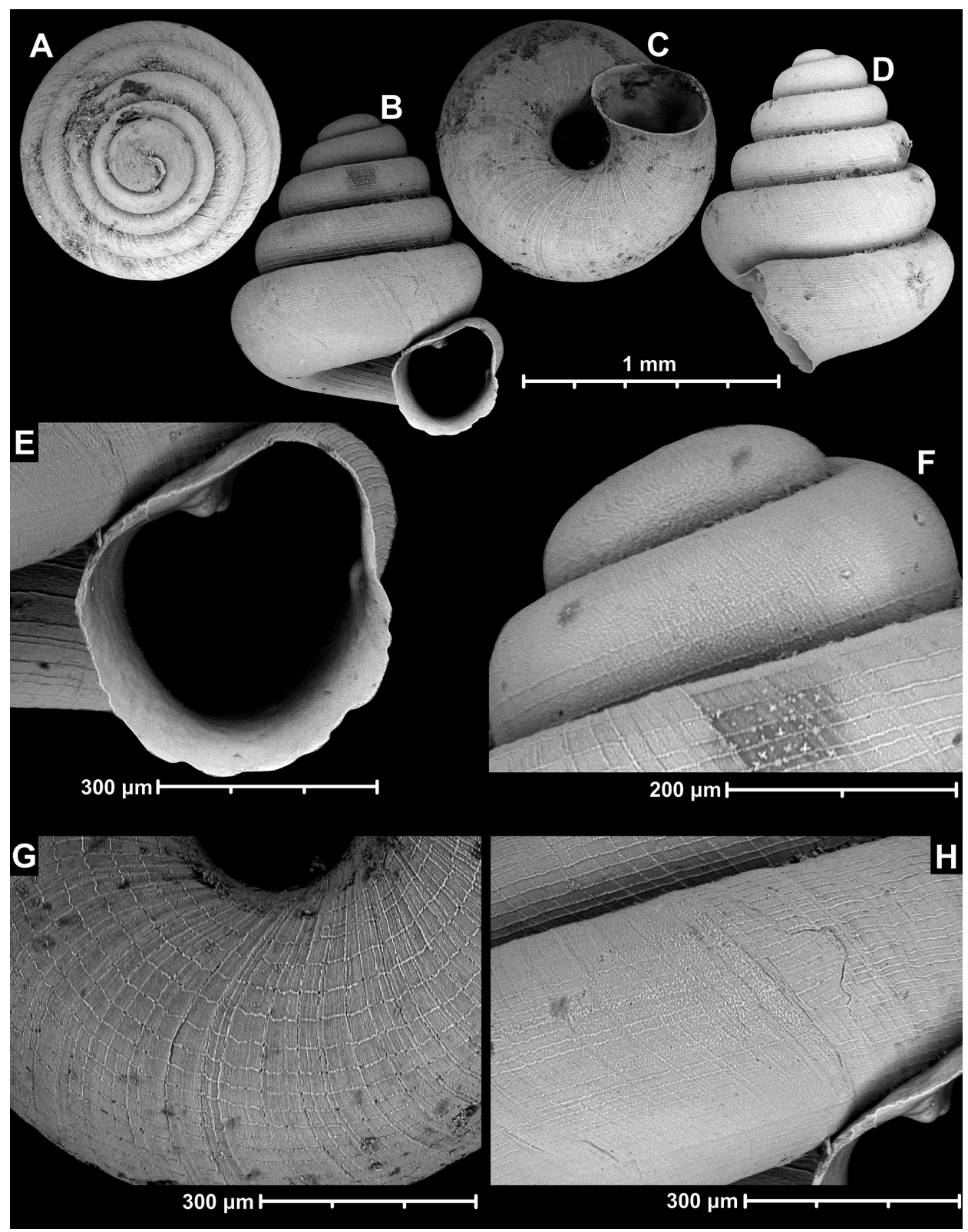

Fig. 3. Angustopila stochi sp. n. B, D and $\mathrm{E}=$ holotype, A, C, F-G = paratype. A-D = different views of the shell, $\mathrm{E}=$ aperture, $\mathrm{F}=$ protoconch, $\mathrm{G}=$ sculpture of the base of the shell (umbilical side), $\mathrm{H}=$ sculpture of the body whorl 
Description: Shell minute, greyish white, very fragile, spire convexly conic with obtuse apex; whorls shouldered; spire tilted slightly left; fine equidistant rows of striae radiate from the nuclear whorl, starting at a zone of granulose wrinkles and continuing onto the teleoconch; teleoconch sculpture finely retiform with irregularly-spaced radial growth lines crossed by fine rows of spiral threads; the 4.75 rounded, evenly increasing whorls are separated by a deep suture; aperture ovate-subquadrate; parietal denticle deeply-set, consisting of three tubercles running inside, the first conspicuously lower than the subsequent two; opposite of the parietal denticle is a small, deeply-set, low palatal plica; distal portion of body whorl forms a short detached tuba; peristome thin at uppermost right region, basally slightly reflected; umbilical zone highly reticulate; umbilicus narrow; penultimate whorl bulges decidedly beyond the plane of the aperture by ca, 1/6 the max. breadth of shell (lateral view).

Measurements (in mm): $\mathrm{SH}=1.26 ; \mathrm{SW}=1.06 ; \mathrm{AH}=0.43 ; \mathrm{AW}=0.42$ (holotype).

Differential diagnosis: Angustopila stochi sp. n. differs from the sympatric $A$. subelevata by the larger shell and the presence of two denticles in the aperture. Three Angustopila species possess two apertural teeth similar to $A$. stochi sp. n., namely, $A$. huoyani, $A$. tamlod and $A$. dominikae. These species are considerably smaller than $A$. stochi. Moreover, $A$. huoyani, $A$. tamlod and $A$. dominikae bear a more pronounced, tuberculated parietal denticle causing the aperture to appear heart-shaped. A. dominikae has a more accentuated palatal denticle and a subglobose-conical shell.

Etymology: This new species is dedicated to Dr. Fabio Stoch, who sent the samples to Dr. Marco Bodon who kindly provided us the material.

Distribution: Angustopila stochi sp. n. is known from sediment samples from the Cong Troi Cave in Northern Vietnam.

Remarks: The last quarter whorl of the holotype (the only known adult shell) got damaged during the SEM imaging. Hence, these two shell fragments are deposited in the MZUF. This breakage is probably due to shell decay on account of its previous preservation in formaldehyde (Marco Bodon, pers. comm.).

\section{Angustopila subelevata Páll-Gergely et Hunyadi, 2015}

$$
\text { (Figs 1B, 2A-G, 7E-F.) }
$$

Angustopila subelevata Páll-Gergely et Hunyadi, In: PÁlL-Gergely et al. 2015, ZooKeys 523: 39-42, Fig. 4.

Material examined: C05-N5 (locality code), Northern Vietnam, Ha Giang Province,

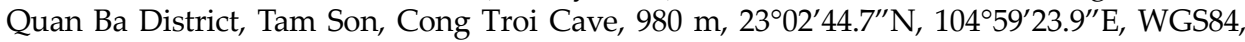
at the entrance, lake with dripping water, leg. G. TomAsIN, 29.01.2010., 2 strongly corroded shells, MZUF GC/49398; C03-N39 (locality code), Northern Vietnam, Ha Giang Province, Quan Ba District, Tam Son, Cong Troi Cave, 980 m, 2302'44.7”N, 10459'23.9' E, WGS84, 
Table 1. Mean, minimum, maximum and standard deviation of shell and aperture sizes in specimens of Angustopila subelevata Páll-Gergely et Hunyadi, 2015 from the Cong Troi Cave, Northern Vietnam (locality 74) $(\mathrm{n}=12)$. Abbreviations: $\mathrm{SH}=$ shell height, $\mathrm{SW}=$ shell width, $\mathrm{AH}=$ aperture height, $\mathrm{AW}=$ aperture width, 100SW/SH = shell width shared with shell height and multiplied by 100,100AW/AH = aperture width shared with aperture height and multiplied by 100.

\begin{tabular}{lcccccc}
\hline & SH & SW & AH & AW & 100SW/SH & 100AW/AH \\
\hline Mean & 0.89 & 0.82 & 0.35 & 0.34 & 93 & 99 \\
Minimum & 0.82 & 0.78 & 0.32 & 0.33 & 83 & 92 \\
Maximum & 0.94 & 0.86 & 0.36 & 0.35 & 99 & 104 \\
Standard deviation & 0.037 & 0.024 & 0.011 & 0.0074 & 5.2 & 3.1 \\
\hline
\end{tabular}

at the entrance, gours of dripping water, leg. G. TomAsin, 28.01.2010., MZUF GC/49404 (1 shell); C04-N74 (locality code), Northern Vietnam, Ha Giang Province, Quan Ba District, Tam Son, Cong Troi Cave, 980 m, 2302'44.7'N, 10459'23.9”'E, WGS84, internal canyon, gours of dripping water, leg. G. Tomasin, 29.01.2010., Specimen 1 (figured shell), Specimen 2 (figured shell), additional 26 shells, MZUF GC/49411; Same data, HNHM 99733/1; Same data, PGB/2.

Measurements (in mm): $\mathrm{SH}=0.82-0.94 ; \mathrm{SW}=0.78-0.86 ; \mathrm{AH}=0.32-0.36 ; \mathrm{AW}=0.33-$ $0.35(\mathrm{n}=12)$ (Table 1$)$.

Distribution: Angustopila subelevata was described from Guangxi, southern China. The locality reported in this paper represents the first locality from Vietnam.

Remarks: The Vietnamese specimens are slightly larger than the type material from Guangxi, China (Min. SH: 0.83, max SH: 0.91, mean: 0.87: PállGergely et al. (2015), but no other conchological differences were found. The parietal callus of one of the shells forms a tooth-like projection (Fig. 7F).

The material examined here has spiral threads on the umbilicus and at the base of the shell in sync with PÁll-Gergely et al. (2015). Panha and Burch (2005) did not observe this characteristic in their investigations of the most similar Thai species Angustopila elevata (Thompson et Upatham, 1997).

\section{Dentisphaera Páll-Gergely et Jochum gen. n.}

Type species: Dentisphaera maxema Páll-Gergely et Jochum, sp. n.

Differential diagnosis: Dentisphaera differs from Angustopila by the presence of six teeth in the aperture, and the elongation of the tuba (most conspicuously visible from dorsal view).

Etymology: The name Dentisphaera refers to the presence of multiple teeth in the peristome and the ovoid, almost spherical shape of the shell. 


\section{Dentisphaera maxema Páll-Gergely et Jochum sp. n. (Figs 1D, 4, 7C-D)}

Type material: C04-N74 (locality code), Northern Vietnam, Ha Giang Province, Quan Ba District, Tam Son, Cong Troi Cave, $980 \mathrm{~m}, 2^{\circ} 02^{\prime} 44.7^{\prime \prime} \mathrm{N}, 104^{\circ} 59^{\prime} 23.9^{\prime \prime} \mathrm{E}$, WGS84, internal canyon, gours of dripping water, leg. G. TomAsin, 29.01.2010., Holotype MZUF GC/49408; Same data, MZUF GC/49409/12 paratypes; Same data, HNHM 99732/1 paratype; Same data, PGB/2 paratypes; Same data, MZUF GC/49410/1 juvenile shell (not paratype); C05-N5 (locality code), Northern Vietnam, Ha Giang Province, Quan Ba District, Tam Son, Cong Troi Cave, $980 \mathrm{~m}, 2^{\circ} 02^{\prime} 44.7^{\prime \prime} \mathrm{N}, 104^{\circ} 59^{\prime} 23.9^{\prime \prime} \mathrm{E}$, WGS84, at the entrance, lake with dripping water, leg. G. TomAsin, 29.01.2010., 2 corroded paratypes, MZUF GC/49397; C03-N39 (locality code), Northern Vietnam, Ha Giang Province, Quan Ba District, Tam Son, Cong Troi Cave, $980 \mathrm{~m}, 2^{\circ} 02^{\prime} 44.7^{\prime \prime} \mathrm{N}, 104^{\circ} 59^{\prime} 23.9^{\prime \prime} \mathrm{E}$, WGS84, at the entrance, gours of dripping water, leg. G. Tomasin, 28.01.2010., Specimen1 (figured paratype), additional 8 paratypes, MZUF GC/49402; Same data, 4 shell fragments (2 apical, 2 lower parts; not paratypes), MZUF GC/49403.

Diagnosis: Shell tiny, ovate-conoid with shouldered whorls, umbilicus narrow, tuba protruding, six robust teeth (1 parietal, 1 angular, 2 palatal, 2 columellar).

Description: Shell minute, ovate, very fragile, light grey with spire convexly conic with obtuse apex; protoconch recessed to the right at antepenultimate whorl; nuclear whorl begins with a pattern of granulose wrinkles, merging into a pattern of dense, shallow pits; the 4.5 convex, unevenly increasing whorls are separated by a deep suture; teleoconch sculpture finely retiform with raised equidistantly-spaced spiral threads; small aperture piriform; six prominent, deeply set denticles form robust barriers; parietal denticle slightly contorted and aligned directly opposite the deeper-set, palatal denticle; angular denticle slants to the right; body whorl thick; aperture oblique to shell axis; tuba end of body whorl detached and projecting slightly downward past penultimate whorl (lateral view); tuba deflects to the right of the umbilicus; umbilical zone faintly reticulate; umbilicus narrow and deep.

Measurements (in mm): $\mathrm{SH}=0.87-1.06 ; \mathrm{SW}=0.85-0.96 ; \mathrm{AH}=0.38-0.45 ; \mathrm{AW}=0.38-$ $0.44(\mathrm{n}=18)$ (Table 2).

Etymology: The specific epithet derives from the Hungarian word "mákszem" (poppy seed), referring to the tiny shell. This name is to be used as a noun in apposition.

Table 2. Mean, minimum, maximum and standard deviation of shell and aperture sizes in specimens of Dentisphaera maxema Páll-Gergely et Jochum sp. $n .(n=18)$. For abbreviations see Table 1.

\begin{tabular}{lcccccc}
\hline & SH & SW & AH & AW & 100SW/SH & 100AW/AH \\
\hline Mean & 0.97 & 0.90 & 0.41 & 0.41 & 94 & 100 \\
Minimum & 0.87 & 0.85 & 0.38 & 0.38 & 98 & 100 \\
Maximum & 1.06 & 0.96 & 0.45 & 0.44 & 91 & 102 \\
Standard deviation & 0.052 & 0.032 & 0.020 & 0.018 & 4.4 & 3.4 \\
\hline
\end{tabular}


Distribution: Dentisphaera maxema sp. $\mathrm{n}$. is known from sediment samples from the Cong Troi Cave in Northern Vietnam.
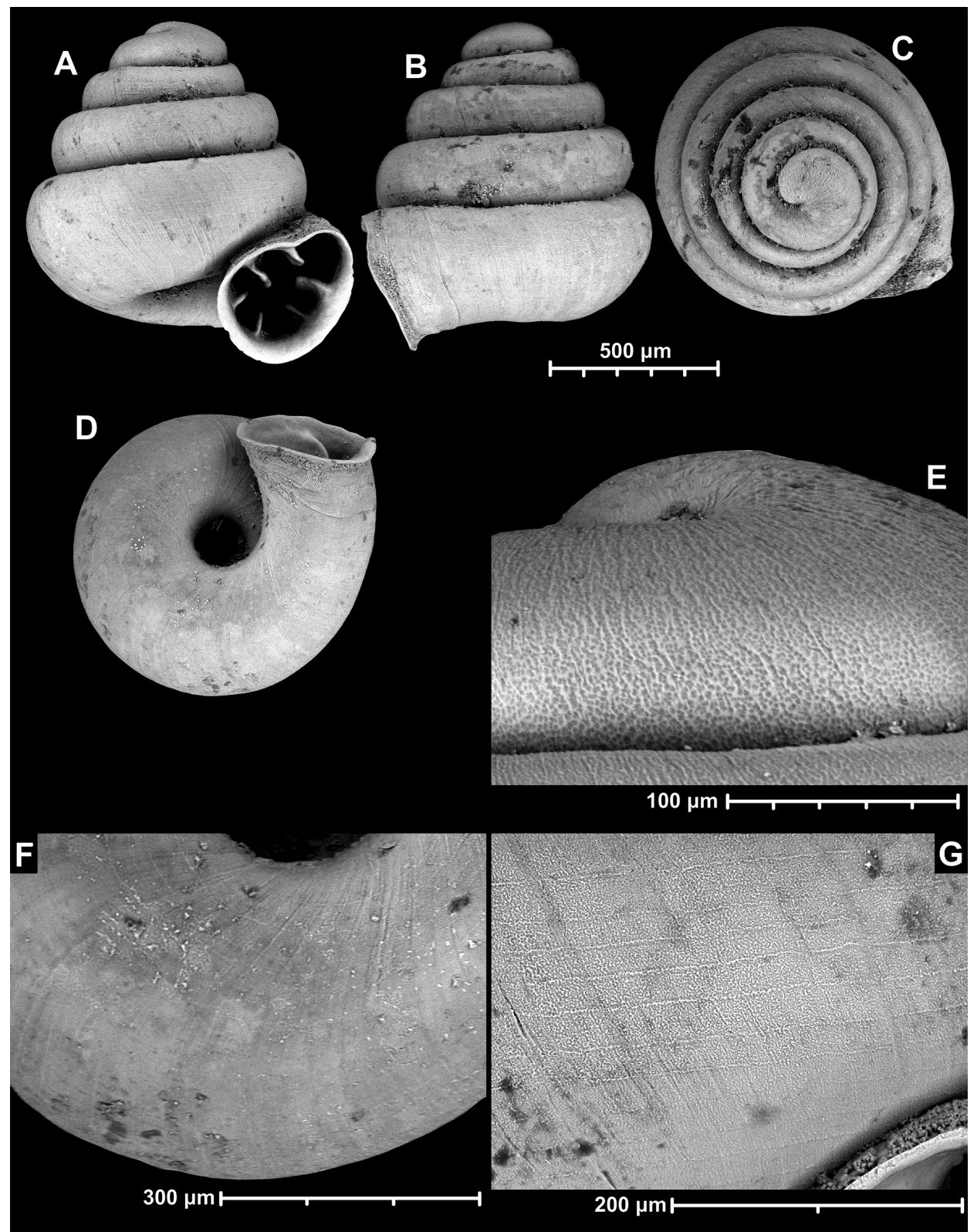

Fig. 4. Holotype of Dentisphaera maxema sp. $\mathrm{n}$. A-D = different views of the shell, E= protoconch, $\mathrm{F}$ = sculpture of the base of the shell (umbilical side), $\mathrm{G}=$ sculpture of the body whorl 


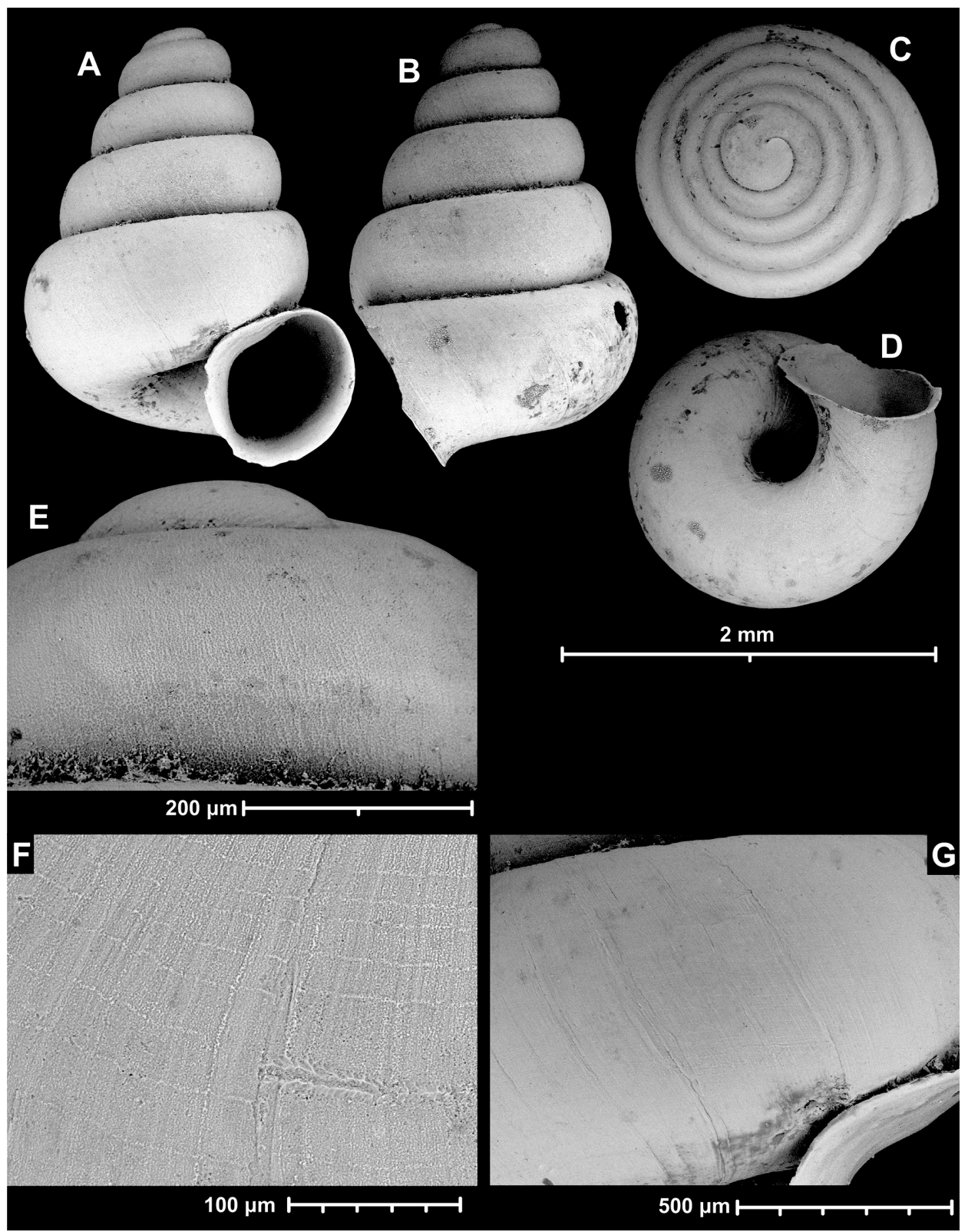

Fig. 5. Holotype of Tonkinospira tomasini sp. $\mathrm{n}$. A-D = different views of the shell, $\mathrm{E}=$ protoconch, $F=$ sculpture of the base of the shell (umbilical side), $G=$ sculpture of the body whorl 


\section{Tonkinospira Jochum, Slapnik et Páll-Gergely, 2014}

Systenostoma Bavay \& Dautzenberg, 1908: Journal de Conchyliologie, 56: 243. not Systenostoma Marsson, 1887 [Bryozoa]. Established as a subgenus of Helix.

Systenostoma - Bavay \& Dautzenberg, 1908, Journal de Conchyliologie, 57: 196. (diagnosis). Tonkinospira Jochum, Slapnik et Páll-Gergely, 2014: In: Jocнum et al., ZooKeys 410: 31.

Type species: Helix (Systenostoma) pauperrima Bavay et Dautzenberg, 1908 by subsequent designation (Pilsbry 1917).

Content: defixa (Bavay et Dautzenberg, 1912), depressa (Jaeckel, 1950), pauperrima (Bavay et Dautzenberg, 1908), pulverea (Bavay et Dautzenberg, 1908), tomasini Páll-Gergely et Jochum, sp. n.

Distribution: Tonkinospira species are known from Northern Vietnam so far (PÁlL-Gergely et al. 2015 and this study).

\section{Tonkinospira tomasini Páll-Gergely et Jochum sp. $\mathrm{n}$.}

$$
\text { (Figs 1A, 5, 6, 7A-B) }
$$

Type material: C03-N39 (locality code), Northern Vietnam, Ha Giang Province, Quan

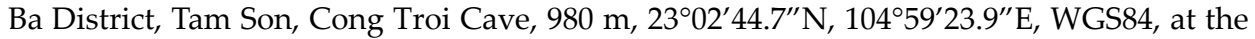
entrance, gours of dripping water, leg. G. Tomasin, 28.01.2010., Specimen1 (= holotype, MZUF GC/49399); Same data, Specimen2 (figured paratype), Specimen3 (figured paratype), additional 4 paratypes, MZUF GC/49400; Same data, HNHM 99731/1 paratype; Same data, PGB/1 paratype; Same data, 2 juvenile shells (not paratypes), MZUF GC/49401; C04-N74 (locality code), Northern Vietnam, Ha Giang Province, Quan Ba District, Tam Son, Cong Troi Cave, $980 \mathrm{~m}, 2^{\circ} 02^{\prime} 44.7^{\prime \prime} \mathrm{N}, 104^{\circ} 59^{\prime} 23.9^{\prime \prime} \mathrm{E}$, WGS84, internal canyon, gours of dripping water, leg. G. Tomasin, 29.01.2010., MZUF GC/49407/1 paratype.

Diagnosis: Small conical shell with convex whorls, less than $1.95 \mathrm{~mm}$ broad; aperture edentate.

Description: Shell convexly conic with obtuse apex, greyish white; nuclear whorl begins with a pattern of granulose wrinkles, merging into a pattern of dense, shallow pits

Table 3. Mean, minimum value, maximum value and standard deviation of a set of values (SD) for Tonkinospira tomasini Páll-Gergely et Jochum sp. n. $(\mathrm{n}=8)$. For abbreviations see Table 1.

\begin{tabular}{lcccccc}
\hline & SH & SW & AH & AW & 100SW/SH & 100AW/AH \\
\hline Mean & 2.41 & 1.80 & 0.84 & 0.87 & 75 & 103 \\
Minimum & 2.23 & 1.70 & 0.79 & 0.82 & 55 & 96 \\
Maximum & 2.98 & 1.93 & 0.91 & 0.94 & 81 & 109 \\
Standard deviation & 0.251 & 0.077 & 0.038 & 0.040 & 5.5 & 4.5 \\
\hline
\end{tabular}




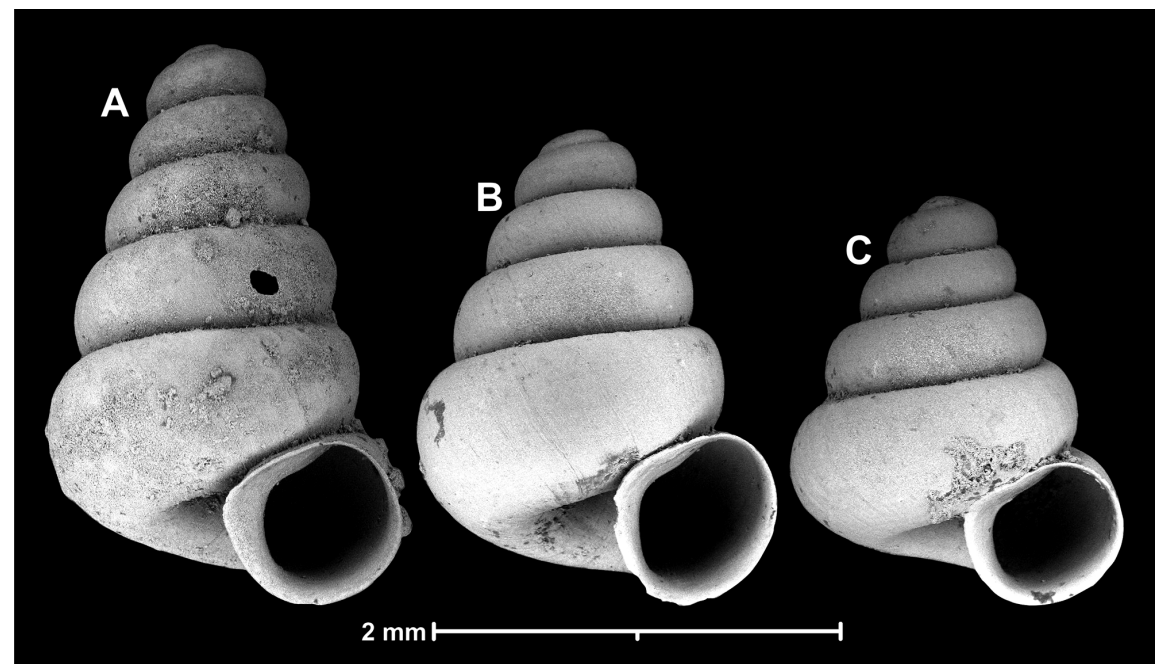

Fig. 6. Variation of shell shape in Tonkinospira tomasini sp. n. A =n39, Specimen2, B =n39, Specimen1 (holotype); $\mathrm{C}=\mathrm{n} 39$, Specimen3

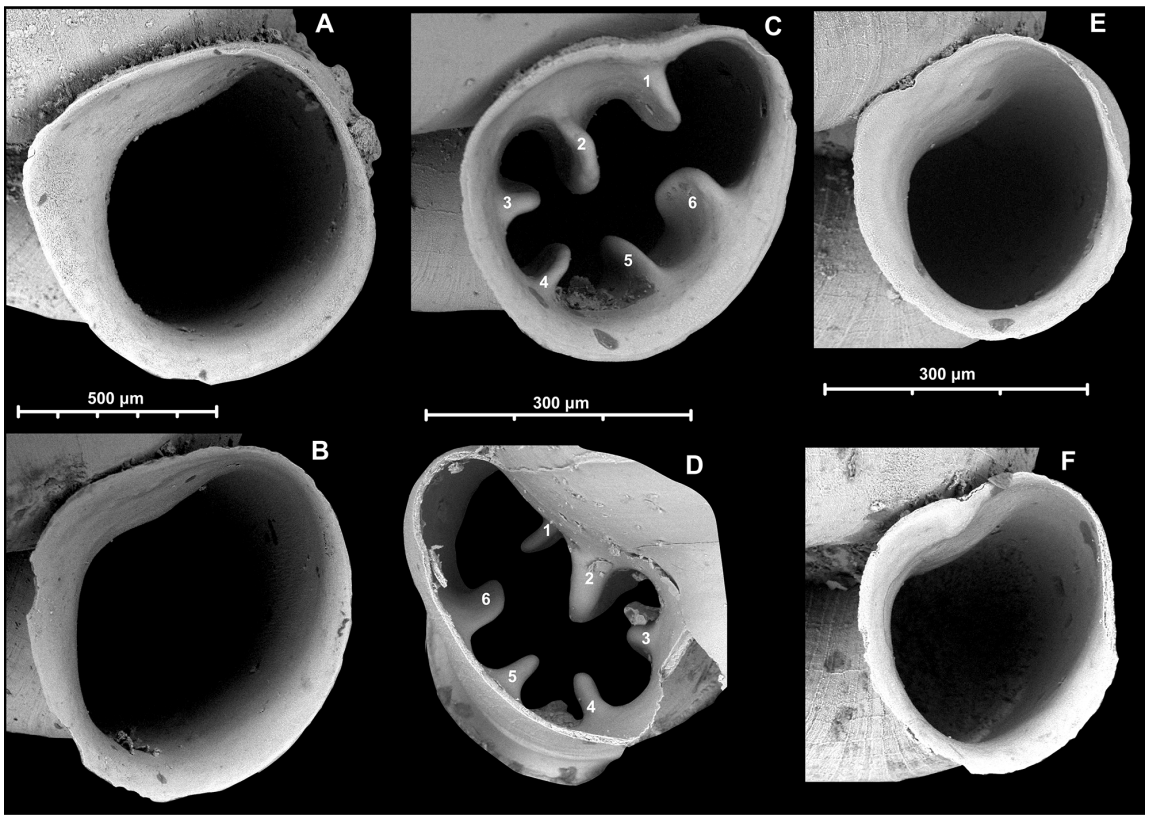

Fig. 7. Apertures of Hypselostomatidae found in the Cong Troi Cave, Ha Giang Province, Northern Vietnam. A-B = Tonkinospira tomasini sp. n. (A = n39, Specimen2, B = n39, Specimen1); C-D = Dentisphaera maxema sp. n. (n39, Specimen1, Fig. D was taken after removing the body whorl), $\mathrm{E}-\mathrm{F}=$ Angustopila subelevata $(\mathrm{E}=\mathrm{n} 74$, Specimen2, $\mathrm{F}=\mathrm{n} 74$, Specimen1). Enumeration of teeth of $D$. maxema are the following. $1=$ angular, $2=$ parietal, $3-4=$ columellar, 5-6 = palatal 
without spiral threads, granular texture; suture deep; protoconch consists of approximately 1.5 whorls; teleoconch retiform with faint spiral threads; protoconch and teleoconch consists of 5 evenly increasing convex whorls; aperture quadrate-reniform, adnate; left outer margin thickly angular with decreasing thickness descending towards the basal margin and ascending towards the upper right portion of the peristome; basal-most section of peristome folds back slightly; distal end of the body whorl does not proceed past penultimate whorl but rather aligns even with the ventral convexity of the penultimate whorl in profile view; distal end of body whorl deflects to the right of the umbilicus; umbilicus narrow and deep.

Measurements (in mm): $\mathrm{SH}=2.23-2.98 ; \mathrm{SW}=1.7-1.93 ; \mathrm{AH}=0.79-0.91 ; \mathrm{AW}=0.82-$ $0.94(\mathrm{n}=8)$ (Table 3).

Differential diagnosis: The most similar Tonkinospira species is T. pauperrima, which has a wider shell, a lower spire and shows a more pronounced spiral striation than T. tomasini sp. $\mathrm{n}$.

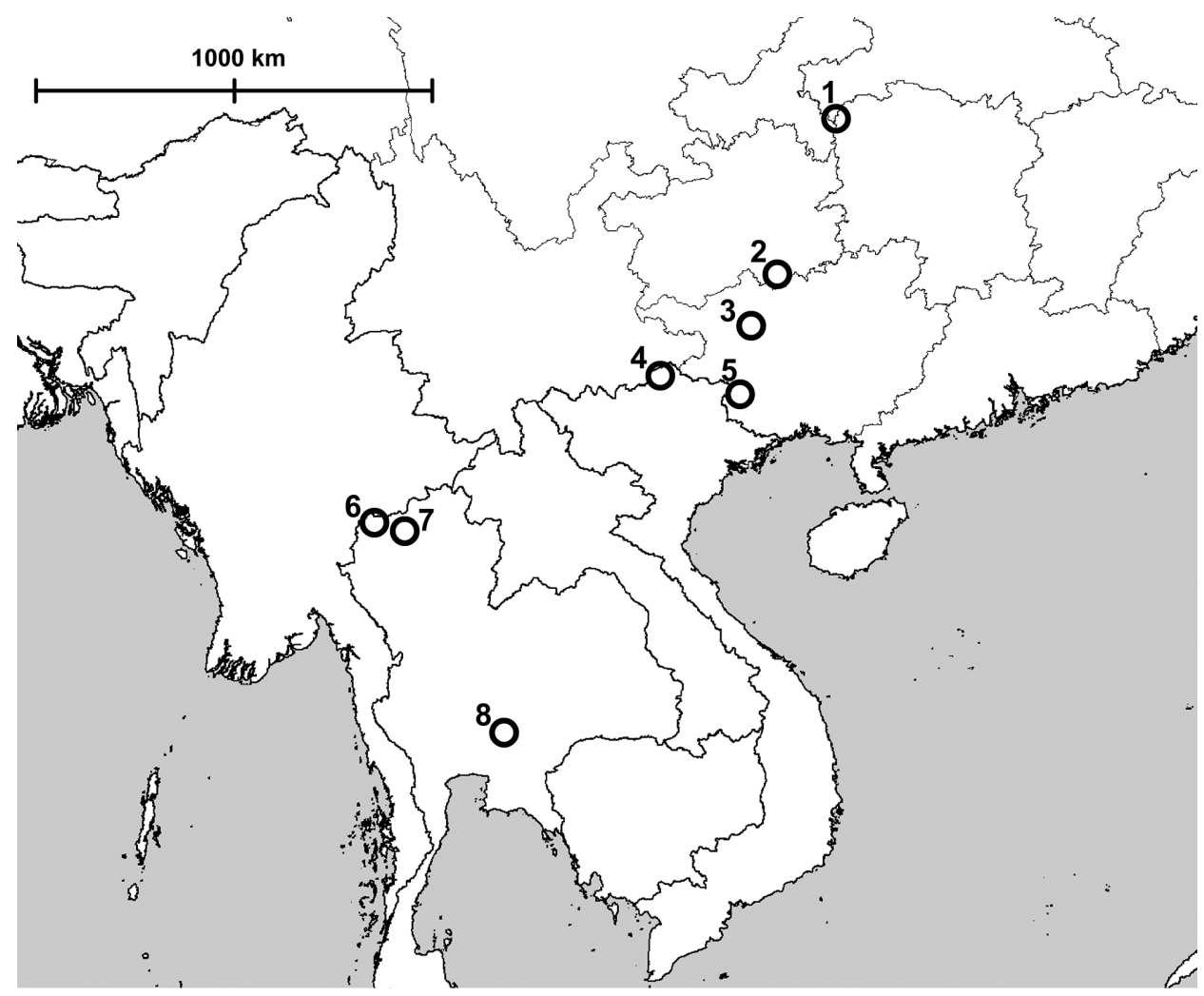

Fig. 8. Distribution of Angustopila species. $1=$ type locality of $A$. huoyani, $2=$ other locality of $A$. huoyani (see Páll-Gergely et al. 2015), 3 = type locality of $A$. dominikae, A. subelevata and $A$. szekeresi, $4=$ type locality of $A$. stochi sp. n. (Cong Troi Cave) and other locality of $A$. subelevata, 5 = type locality of $A$. fabella, $6=$ type locality of $A$. tamlod, $7=$ type locality of $A$. 
Etymology: The new species is named after G. Tomasin, who collected the material from Cong Troi Cave.

Distribution: Tonkinospira tomasini sp. n. is known from sediment samples from the Cong Troi Cave in Northern Vietnam.

Acknowledgements - We are thankful to Gianfranco Tomasin for collecting the snails described herein, to Fabio Stoch who organized the sorting logistics and to Marco Bodon for enabling us to examine this material. The material was collected during the ItalianVietnamese Speleological Multidisciplinary Expedition (I.V.S.M.E.) organized by the scientific association, Karst Water Exploring (K.a.W.E.) in Trieste, Italy. This work was made possible through joint collaboration with other institutions and the Hanoi University of Mining and Geology. Many thanks are due to Clarissa Brun (president of K.a.W.E.) and Paolo Bono (University of Rome "La Sapienza"). We are grateful to Katsura Yamada (Shinshu University) for helping us measure the shells, and for two anonymous reviewers for commenting on the manuscript. This study was supported by Grants-in-Aid for Scientific Research (KAKENHI) from the Japan Society for the Promotion of Science to T. Asami. Barna Páll-Gergely is an International Research Fellow of the Japan Society for the Promotion of Science.

\section{REFERENCES}

Ancey, C.-F. (1881): Descriptions de mollusques terrestres nouveaux. - Le Naturaliste: Journal des échanges et des nouvelles 1(47): 373-374.

Bavay, A. \& Dautzenberg, Ph. (1908): Molluscorum terrestrium Tonkinorum diagnoses. Journal de Conchyliologie 56: 229-251.

Bavay, A. \& Dautzenberg, Ph. (1909): Description de coquilles nouvelles de l'Indo-Chine. - Journal de Conchyliologie 57: 163-206.

Bavay, A. \& Dautzenberg, Ph. (1912): Description de coquilles nouvelles de l'Indo-Chine. - Journal de Conchyliologie 60: 1-54.

Benson, W. H. (1856): Remarks on the genera Tanystoma, Nematura, and Anaulus. The Annals and Magazine of Natural History 2(17): 342-343. https://doi.org/10.1080/ 00222935608697520

Inkhavilay, K., Sutcharit, C., Tongkerd, P. \& Panha, S. (2016): New species of micro snails from Laos (Pulmonata: Vertiginidae and Diapheridae). - Journal of Conchology 42(4): 213-232.

JAECKel, S. H. (1950): Die Mollusken eines tropischen Flußgenistes aus Tonkin. - Archiv für Molluskenkunde 79: 15-20.

Jochum, A., Slapnik, R., Kampschulte, M., Martels, G., Heneka, M. \& Páll-Gergely, B. (2014): A review of the microgastropod genus Systenostoma Bavay \& Dautzenberg, 1908 and a new subterranean species from China (Gastropoda, Pulmonata, Hypselostomatidae). - ZooKeys 410: 23-40. https://doi.org/10.3897/zookeys.410.7488

Kerney, M. P. \& Cameron, R. A. D. (1979): A field guide to the land snails of Britain and Northwest Europe. - Collins, London, 288 pp. 
Marsson, T. F. (1887): Die Bryozoen der weissen Schreibkreide der Insel Rügen. - Paläontologische Abhandlungen 4: 1-122.

MöLlendorfF, O. F. von (1890): Die Landschnecken-Fauna der Insel Cebu. - Bericht über die Senckenbergische Naturforschende Gesellschaft in Frankfurt am Main 1889-1890: 189-292.

Páll-Gergely, B., Hunyadi, A., Jochum, A. \& Asami, T. (2015): Seven new hypselostomatid species from China, including some of the world's smallest land snails (Gastropoda, Pulmonata, Orthurethra). ZooKeys 523:31-64. https://doi.org/10.3897/zookeys.523.6114

Panha, S. \& Burch, J. B. (1999): New taxa of Pupillidae (Pulmonata: Stylommatophora) from Thailand. - Walkerana 10(24): 113-134.

PAnha, S. \& Burch, J. B. (2005): An introduction to the microsnails of Thailand. - Malacological review 37-38: 1-155.

Pfeiffer, L. (1849): Neue Molluskengattungen. - Zeitschrift für Malakozoologie 6: 97-105.

Pilsbry, H. A. (1892): New mollusks of St. Helena. - The Nautilus 6: 96.

Pilsbry, H. A. (1916-1918): Manual of Conchology, Second Series: Pulmonata, Vol. 24, Pupillidae (Gastrocoptinae). - Conchological Department, Academy of Natural Sciences of Philadelphia, Philadelphia, 380 pp., plates 1-50.

Pilsbry, H. A \& Vanatta, E. G. (1900): A partial revision of the Pupæ of the United States. - Proceedings of the Academy of Natural Sciences of Philadelphia 52: 582-611.

Sсніцеуко, A. A. (1998): Treatise on recent terrestrial pulmonate molluscs. Part 2. Gastrocoptidae, Hypselostomatidae, Vertiginidae, Truncatellinidae, Pachnodidae, Enidae, Sagdidae. - Ruthenica Suppl. 2: 129-262.

SсніLеуко, A. A. (2011): Check-list of land pulmonate molluscs of Vietnam (Gastropoda: Stylommatophora). - Ruthenica 21(1): 1-68.

Stoliczka, F. (1873): On the land-shells of Penang island, with descriptions of the animals and anatomical notes; part second, Helicacea. - Journal of the Asiatic Society of Bengal 42(2): 11-38.

Thompson, F. G. \& Dance, S. P. (1983): Non-marine mollusks of Borneo. II Pulmonata: Pupillidae, Clausiliidae. III Prosobranchia: Hydrocenidae, Helicinidae [J]. - Bulletin of the Florida Museum of Natural History, Biological Sciences 29(3): 101-152.

Tномpson, F. G. \& Upatнaм, S. (1997): Vertiginid land snails from Thailand (Gastropoda, Pulmonata, Pupilloidea). - Bulletin of the Florida Museum of Natural History, Biological Sciences 39(7): 221-245.

Tomlin, J. R. (1930): Some preoccupied generic names. - Proceedings of the Malacological Society of London 19: 22-24.

Tongkerd, P., Lee, T., Panha, S., Burch, J. B. \& O’Foighil, D. (2004): Molecular phylogeny of certain Thai gastrocoptine micro land snails (Stylommatophora: Pupillidae) inferred from mitochondrial and nuclear ribosomal DNA sequences. - Journal of Molluscan Studies 70: 139-147. https://doi.org/10.1093/mollus/70.2.139

ZıLch, A. (1959-1960): Handbuch der Paleozoologie, 6 (2) Euthyneura. - Gebrüder Borntraeger, Berlin, pp. 481-834.

Received February 17, 2016, accepted March 3, 2016, published July 21, 2017 